\title{
Origin of Oligodendrocytes within the Human Spinal Cord
}

\author{
Mohammad Hajihosseini, To Nam Tham, and Monique Dubois-Dalcq \\ Unité de Neurovirologie et Régénération du Système Nerveux, Institut Pasteur, 75015 Paris, France
}

\begin{abstract}
To determine the time and site of origin of the oligodendrocyte lineage in the developing human spinal cord, we have examined tissues from 45 to $83 \mathrm{~d}$ postconception (dpc) using sets of probes and antibodies recognizing oligodendrocyte-specific glycolipids, transcripts, and proteins. We found that two clusters of oligodendrocyte precursors appear on or before $45 \mathrm{dpc}$ on each side of the cord ventral ependyma above the floor plate. These precursors express glycolipids recognized by the $\mathrm{O} 4$ and Rmab antibodies, platelet-derived growth factor $\alpha$-receptor, myelin basic protein (MBP), and 2' $3^{\prime}$-cyclic nucleotide $3^{\prime}$ phosphodiesterase as well as MBP and proteolipid transcripts. Expression of the morphogen sonic hedgehog was detected in the floor plate at $45 \mathrm{dpc}$ and decreased at $58 \mathrm{dpc}$. During this period, oligodendrocyte precursors emerged in the ventral and lateral region of the forming white matter, a process
\end{abstract}

occurring first in cervical and later in lumbar cord. The majority of $\mathrm{O}^{+}$cells express the proliferating cell nuclear antigen (PCNA), and their pattern of dispersion suggests that these cells progressively populate the lateral and dorsal cord regions. Oligodendrocytes expressing galactocerebroside appeared at $53 \mathrm{dpc}$ and did not express PCNA. Oligodendrocyte precursors were detected in dorsal cord regions at $74 \mathrm{dpc}$ and at $83 \mathrm{dpc}$ when myelination started in the ventral roots. Thus, oligodendrocyte precursors expressing myelin transcripts and proteins emerge in the ventral region of the embryonic cord several weeks before myelination.

Key words: oligodendrocyte origin; developing human spinal cord; myelin gene transcripts; in situ hybridization; immunolabeling of myelin specific glycolipids and proteins; plateletderived growth factor $\alpha$ receptor
Little is known about the origin and development of human oligodendrocytes, the CNS myelin-forming cells. In the human spinal cord, myelination begins at approximately 10-11 weeks of gestation (WG) (Gamble, 1969; Weidenheim et al., 1992), whereas cells expressing myelin basic protein (MBP) are detected by immunocytochemistry in the cord at $9 \mathrm{WG}$ (Weidenheim et al., 1993). Moreover, oligodendrocytes are found in cultures of fetal spinal cord and brain at 7 and $12 \mathrm{WG}$, respectively (Dickson et al., 1985; Aloisi et al., 1992; Sato and Kim, 1994). Much more is known about oligodendrocyte development in rodent and chick. With use of retroviral vector tagging, oligodendrocytes were shown to derive in vivo from precursors in embryonic day 16 (E16) rat cerebral cortex (Grove et al., 1993; Luskin et al., 1993) and in vitro from multipotential cortical precursors as early as E12 (Davis and Temple, 1994; Williams and Price, 1995). Such precursors also exist in the developing chick spinal cord (Leber and Sanes, 1995). Postnatal precursors migrating out of the periventricular zone in the rat generate mostly oligodendrocytes in the white matter and astrocytes and oligodendrocytes in the gray matter (Levison and Goldman, 1993).

During development, oligodendrocyte progenitors can be isolated from postnatal rat optic nerve, brain, cerebellum, and spinal

Received Aug. 5, 1996; revised Sept. 26, 1996; accepted Sept. 30, 1996.

We thank the Myelin Project, Washington, DC, for the fellowship support to $\mathrm{M}$. Hajihosseini, and the Birth Defect Research Laboratory of the University of Washington for providing most of the tissues for this study with the support of National Institutes of Health/National Institute of Child and Human Development Grant HD 00836. We are grateful to M. H. Buc-Caron, Hôpital Pitié- Salpetrière, Paris, for her expert advice and for providing some of the earliest embryonic tissues. We also thank all of our colleagues who donated antibodies and probes for this study.

Correspondence should be addressed to Monique Dubois-Dalcq, Unité de Neurovirologie et Régénération du Système Nerveux, Département de Virologie, Institut Pasteur, 25 Rue du Dr. Roux, 75015 Paris, France.

M. Hajihosseini's present address: Viral Carcinogenesis Laboratory, Imperial Cancer Research Fund, Lincoln's Inn Field, London WC 2A 3PX, UK.

Copyright (C) 1996 Society for Neuroscience $0270-6474 / 96 / 167981-14 \$ 05.00 / 0$ cord (Raff et al., 1989; Dubois-Dalcq and Amstrong, 1992).These progenitors are bipolar in shape, respond to PDGF by mitosis and migration, and express platelet-derived growth factor $\alpha$ receptor (PDGF-R $\alpha$ ) (Mc Kinnon et al., 1990; Ellison and De Vellis, 1994; Richardson et al.,1996). Axonal-derived signals regulate the growth of progenitor cells and the survival of oligodendrocytes (Barres and Raff, 1996). During differentiation, oligodendrocyte progenitors become multipolar and express the prooligodendroblast antigen (POA) followed by sulfatides detected by the $\mathrm{O} 4$ antibody and subsequently galactocerebroside (GC), the major glycolipid of myelin, as well as the myelin enzyme 2',3'-cyclic nucleotide 3' phosphodiesterase (CNP) (Braun et al., 1988; Bansal et al., 1992; Pfeiffer et al., 1993). Postmitotic oligodendrocytes then start to express the major myelin proteins MBP and proteolipid protein (PLP) in vitro and in vivo (Dubois-Dalcq et al., 1985; Monge et al., 1986). Although the synthesis of these myelin proteins is tightly coordinated with myelination, their genes also encode transcripts that are expressed during embryonic CNS development (Ikenaka et al., 1992; Timsit et al., 1992; Nakayima et al., 1993).

In birds and rodents, the first oligodendrocytes originate in the ventral region of the spinal cord (Miller, 1996). In E14 rat or mouse and in E6 chick, two clusters of cells expressing PDGF-R $\alpha$ and CNP transcripts, or stained with $\mathrm{O} 4$ antibody, were found on each side of the ventral ventricular zone (VZ), whereas cells expressing PLP/DM20 were detected in a nearby region (Pringle and Richardson, 1993; Yu et al., 1994; Ono et al., 1995; Timsit et al., 1995). Later, oligodendrocyte precursors also emerge in the lateral and dorsal marginal zones (MZs) of spinal cord (see previously cited references). Sonic hedgehog (shh), a protein synthesized by notocord and floor plate cells that induces motor neuron differentiation in the ventral cord (Marti et al., 1995; Roelink et al., 1995), may play a role in these events. 
Here we describe the origin of human oligodendrocyte precursors within the embryonic spinal cord. Using various probes and antibodies recognizing oligodendrocyte-specific glycolipids, transcripts, and proteins, we show that cells of the human oligodendrocyte lineage first emerge in the ventral region of the embryonic spinal cord at $45 \mathrm{~d}$ postconception (dpc) on each side of the VZ, dorsal to the floor plate where shh is detected, and that oligodendrocytes later disperse into the ventrolateral and dorsal regions of the cord.

\section{MATERIALS AND METHODS}

Tissue collection. Human fetal spinal cords from 32 human embryos and fetuses were provided by the Birth Defect Research Laboratory, University of Washington (Seattle, WA), supported by National Institutes of Health/National Institute of Child Health and Human Development Grant HD 00836. Fetal age was determined according to foot length and expressed in dpc. The tissues were obtained with the consent of the mothers; the consent form as well as the project had been approved by the institutional IRB number 26-0722-A (until May, 1997). Freshly dissected spinal cord tissues from 45 to 83 dpc either were fixed in Bouin's fixative or $4 \%$ freshly prepared formaldehyde or were frozen directly in dry ice and shipped as such or in fixative.

Primary antibodies. Human fetal spinal cord sections were stained with the following antibodies: a mouse monoclonal anti-MBP that recognizes a peptide encoded by exon $6\left(\operatorname{IgG}_{1}\right.$ class/1: 1000 dilution; Boehringer Mannheim, Mannheim, Germany); rabbit anti-CNP (1:200 dilution; gift of Dr. Art F. McMorris, Wistar Institute, Philadelphia, PA; Sprinkle et al., 1985); rabbit anti-shh (1:200 dilution; gift of Dr. A. McMahon, Harvard University, Cambridge, MA; Bumcrot et al., 1995); and a rabbit antibody R7 directed against a peptide corresponding to the cytoplasmic domain of the human PDGF-R $\alpha$ (gift of Dr. C. H. Heldin, Ludwig Institute for Cancer Research, Uppsala, Sweden; Nishiyama et al., 1996). A mouse monoclonal anti-PCNA antibody (IgG2a class, used at 1:200 dilution) was purchased from Boehringer Mannheim.

All glycolipid antibodies were characterized previously (Sommer and Schachner, 1981; Bansal et al., 1989, 1992; Pfeiffer et al., 1993). Mouse O4 antibody recognizes POA, sulfatides, and seminolipid, whereas O1 antibody recognizes GC; both are IgM antibodies (1:5 dilution; Boehringer Mannheim); the Ranscht mouse monoclonal antibody (Rmab) recognizes GC and sulfatide as well as an early oligodendrocyte surface antigen emerging shortly before GC ( $\mathrm{IgG}$, used at 1:3; Boehringer Mannheim).

Immunoperoxidase staining of vibratome sections. Transverse sections $50-60 \mu \mathrm{m}$ thick were prepared from Bouin's-fixed human fetal spinal cords using a Lancer series 1000 vibratome. Consecutive floating sections were collected in ice-cold $2 \mathrm{mM} \mathrm{MgCl} / / 0.1 \mathrm{M}$ PBS solution and stored at $4^{\circ} \mathrm{C}$ in this buffer until they were stained in 24-well plates. Before staining, sections were washed twice in PBS for 10 min to remove traces of Bouin's fixative. Endogenous cellular peroxidase activity was blocked by incubating sections for 30 min with a $3 \%$ hydrogen peroxide/methanol solution cooled to $-20^{\circ} \mathrm{C}$. After sections were rinsed twice in PBS, they were incubated for 40 min with $10 \%$ normal goat serum (NGS/PBS) and then overnight at $4^{\circ} \mathrm{C}$, with either anti-MBP, anti-CNP, or anti-shh antibodies diluted in NGS/PBS. Sections were always washed three times in PBS between each incubation.

Sections were then incubated for $40 \mathrm{~min}$ at room temperature with the appropriate biotinylated-secondary antibodies: goat-anti-mouse $\operatorname{IgG}(1$ : 700 dilution) for MBP antibody or goat-anti-rabbit IgG (1:500 dilution) for CNP and shh antibodies (both from Vector, Biosys, France). Sections were then treated for $40 \mathrm{~min}$ with peroxidase-conjugated avidin-D (1: 1000 in NGS/PBS; Vector) followed by two washes with a 0.05 M Trischloride before carrying out the DAB reaction (Vector Peroxidase substrate kit). DAB reaction was stopped by three washes before the sections were mounted onto $0.5 \%$ gelatin-coated slides. Sections were then taken through a graded series of alcohols and histoclear, allowed to dry, and overlaid with Permount (Fisher Scientific) before being coverslipped.

Freezing and cryocutting. Cryostat sections of formaldehyde-fixed fetal spinal cords were routinely generated under RNase-free conditions so that sections could be used for in situ hybridization with riboprobes (see below) as well as with immunofluorescence staining with antibodies. For this, human fetal spinal cords were fixed by immersion in $4 \%$ formaldehyde/PBS solution, $\mathrm{pH} 7.4$, prepared with diethyl pyrocarbonate-treated distilled water. Fetal cords were post-fixed for $24 \mathrm{hr}$ in $4 \%$ formaldehyde before being treated overnight with a $0.5 \mathrm{~m}$ sucrose solution. Fetal cords were then cut into several fragments according to various axial levels, embedded in TissueTeck/O.C.T. compound (Miles, Bayer Diagnostics), frozen on dry ice, and kept at $-70 \mathrm{C}$ until use. Transverse sections 10-12 $\mu \mathrm{m}$ thick were prepared from frozen cords and thaw-mounted on glass slides previously baked overnight at $250^{\circ} \mathrm{C}$ and coated with $2 \%$ 3 -aminopropyltriethoxysilane solution. Slides then were placed consecutively into numbered slots of plastic boxes and stored at $-70^{\circ} \mathrm{C}$ until immunostaining or in situ hybridization.

Immunofluorescence staining of cryostat sections. Sections were allowed to thaw briefly before being fixed for $15 \mathrm{~min}$ with $4 \%$ formaldehyde solution, $\mathrm{pH}$ 7.4. After two rinses with PBS, nonspecific binding sites within the tissue were blocked by $40 \mathrm{~min}$ incubation with a $3 \%$ bovine serum albumin $/ 5 \%$ NGS solution prepared in PBS. In the case of the PDGF-R $\alpha$ antibody, some sections were stained without prefixation, which often leads to detachment of the sections, or after a short formaldehyde fixation.

Fixed sections were then rinsed twice with PBS and incubated for 40-60 min with primary antibodies, O4 or O1, Rmab, or PDGF-R $\alpha$ antibody. (Sections were always washed three times in PBS between each incubation.) Sections were then incubated for $40 \mathrm{~min}$ with the appropriate secondary antibodies: RITC-coupled goat-anti-mouse IgM (1:100 dilution) for $\mathrm{O} 1$ and $\mathrm{O} 4, \mathrm{Fc}_{\mathrm{g}}$ fragment-specific, biotinylated-goat antimouse IgG (1:50 dilution), both from Jackson ImmunoResearch Labs (West Grove, PA), followed by FITC-streptavidin (1:200 dilution; Vector) for Rmab as well as goat anti-rabbit fluorescein (Jackson ImmunoResearch Labs) for PDGF-R $\alpha$ antibody.

For double-labeling with $\mathrm{O} 4$ or $\mathrm{O} 1 \mathrm{IgM}$ and anti-PCNA IgG, sections were first stained with $\mathrm{O} 4$ or $\mathrm{O} 1$ and IgM-rhodamine as described above, and then treated for $10 \mathrm{~min}$ with a $5 \%$ acetic acid/95\% absolute alcohol solution cooled previously to $-20^{\circ} \mathrm{C}$. After they were washed, the sections were blocked with NGS/PBS and incubated overnight with anti-PCNA antibody before being washed and incubated with $\mathrm{Fc}_{\mathrm{g}}$ fragment-specific biotinylated-goat anti-mouse $\operatorname{IgG}$, followed by FITC-streptavidin antibody, as described for Rmab staining.

All sections were then washed, overlaid with mounting medium Vectashield (Vector) and coverslipped, drained, and sealed with clear nail varnish. Preparations were photographed on a Leica Optovar microscope equipped with appropriate rhodamine and fluorescent filters.

In situ hybridization. Radioactive riboprobes for PLP, MBP, PDGF-R $\alpha$, and CNP were prepared as follows. PLP sense and antisense probes were generated by in vitro transcription of a 0.9 kilobase $(\mathrm{kb})$ SacI-EcoRI insert containing the entire mouse PLP coding region cloned into pGEM3 (PL H116; gift of Dr. L. Hudson, National Institutes of Health, Bethesda, MD), using T7 and SP6 RNA polymerases, respectively. The mouse and human PLP genes have a high sequence homology (Hudson, 1990). MBP probes were produced from a $0.56 \mathrm{~kb}$ EcoRI-SmaI insert containing the entire coding region of human MBP (gift of Dr. Steve Scherer, University of Pennsylvania, Philadelphia, PA; Kamholz et al., 1986) cloned into pBS. In this case, transcription with T3 and T7 RNA polymerases yielded sense and antisense probes, respectively.

PDGF-R $\alpha$ probes were generated by in vitro transcription of a $1.5 \mathrm{~kb}$ SacI-PvuII insert encoding the extracellular domain of rat PDGF-R $\alpha$ receptor cloned in pGEM1 (gift of Dr. W. Richardson), a region that has $83 \%$ homology to the human PDGF-R $\alpha$ (Lee et al., 1990). Transcription with SP6 and T7 RNA polymerases produced riboprobes of sense and antisense orientation, respectively. CNP probes were generated from a $2.8 \mathrm{~kb} E c o$ RI-EcoRI insert containing the entire $1.2 \mathrm{~kb}$ coding region of rat CNP gene cloned into pGEM1 (gift of A. F. McMorris, Wistar Institute, Philadelphia, PA; Bernier et al., 1987). Rat and human CNP genes show an $82 \%$ sequence homology. Sense and antisense CNP probes were produced by transcription with T7 and SP6, respectively.

All probes were radioactively labeled by in vitro transcription in the presence of $\left[{ }^{35} \mathrm{~S}\right] \mathrm{UTP}$ (ICN Pharmaceuticals). Ten- to twelvemicrometer-thick cryostat sections of human fetal spinal cords of different ages were prepared as described above and incubated with one of four ${ }^{35} \mathrm{~S}$-labeled riboprobes. In most cases, the sections that were used were semi-adjacent to those stained with $\mathrm{O} 4$ or Rmab antibodies. For each hybridization, cryostat sections of P10 rat cerebellum were used as positive controls (Kristensson et al., 1986; Jordan et al., 1989). With all probes, clustering of silver grains could be detected over cells present in the cerebellar white matter and peduncle. Hybridization with ${ }^{35} \mathrm{~S}$-labeled riboprobes was performed as described by Pringle et al. $(1989,1992)$, but the following were omitted: the prehybridization step, treatment with nonradioactive UTP, and predigestion with pronase. Briefly, sections 

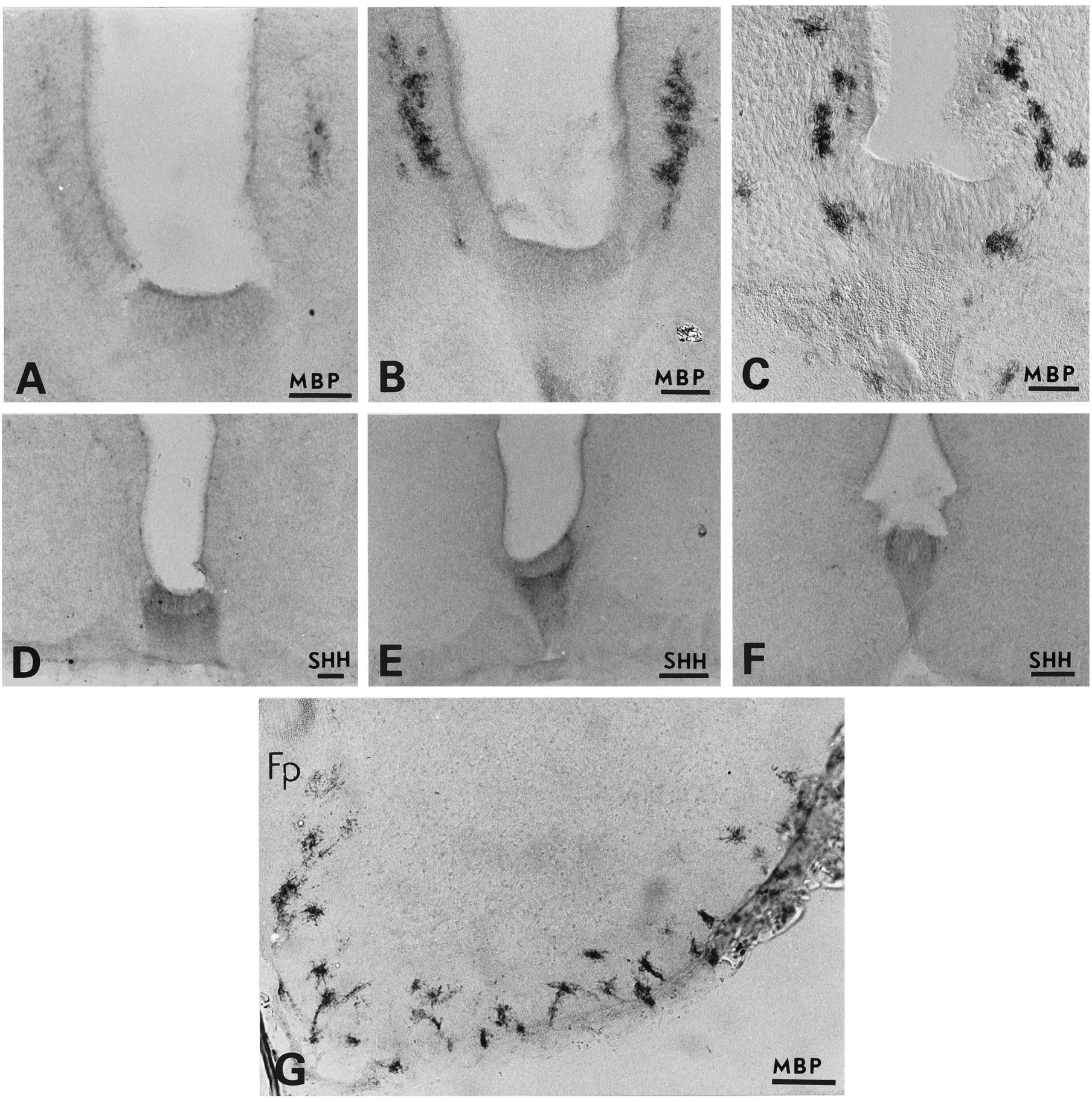

Figure 1. Emergence and dispersion of MBP-immunoreactive cells and expression of sonic hedgehog within the ventral part of human embryonic spinal cord. Immunoperoxidase labeling of Bouin's-fixed vibratome sections. Note a discrete cluster of $M B P$ staining on the right at $45 \mathrm{dpc}(A)$. In $B$, two intensely stained cell clusters are detected at $52 \mathrm{dpc}$ on each side of the VZ, whereas at $54 \mathrm{dpc}(C) \mathrm{MBP}^{+}$cells appear in ventral and lateral regions and finally emerge all along the ventral forming white matter at $57 \mathrm{dpc}(G) . D-F$ show expression of sonic hedgehog $(S H H)$ exclusively by floor plate cells at 45,52 , and $58 \mathrm{dpc}$, respectively. Note the weaker stain at $58 \mathrm{dpc} . F p$, Floor plate. Scale bars: $A-C, G, 100 \mu \mathrm{m} ; D-F, 200 \mu \mathrm{m}$.

were fixed with $4 \%$ formaldehyde, acetylated with $0.1 \mathrm{~m}$ triethanolamine, pH 8.1/acetic anhydride, dehydrated, and either hybridized immediately overnight at $55^{\circ} \mathrm{C}$ with riboprobes or stored at $-70^{\circ} \mathrm{C}$ for later hybridization. Sections were washed, dehydrated, and air-dried before slides were coated with Kodak NTB2 photographic emulsion (diluted 1:1 with $0.6 \mathrm{M}$ ammonium acetate solution at $42^{\circ} \mathrm{C}$ ). Coated slides were kept for 2-3 weeks at $4^{\circ} \mathrm{C}$. At desired time points, slides were developed in Kodak D19 developer, treated with $1 \%$ acetic acid, fixed in $30 \%$ sodium thiosulfate, and washed with distilled $\mathrm{H}_{2} \mathrm{O}$ before they were stained with hematoxylin, dehydrated, and mounted with Permount and glass coverslips. Dark-field photographs were taken on a Leica Optovar microscope.

\section{RESULTS}

During spinal cord development, several cell layers are formed by migration of neural cells out of the germinal VZ (Jacobson, 1991). Initially, postmitotic neurons appear in the intermediate zone 

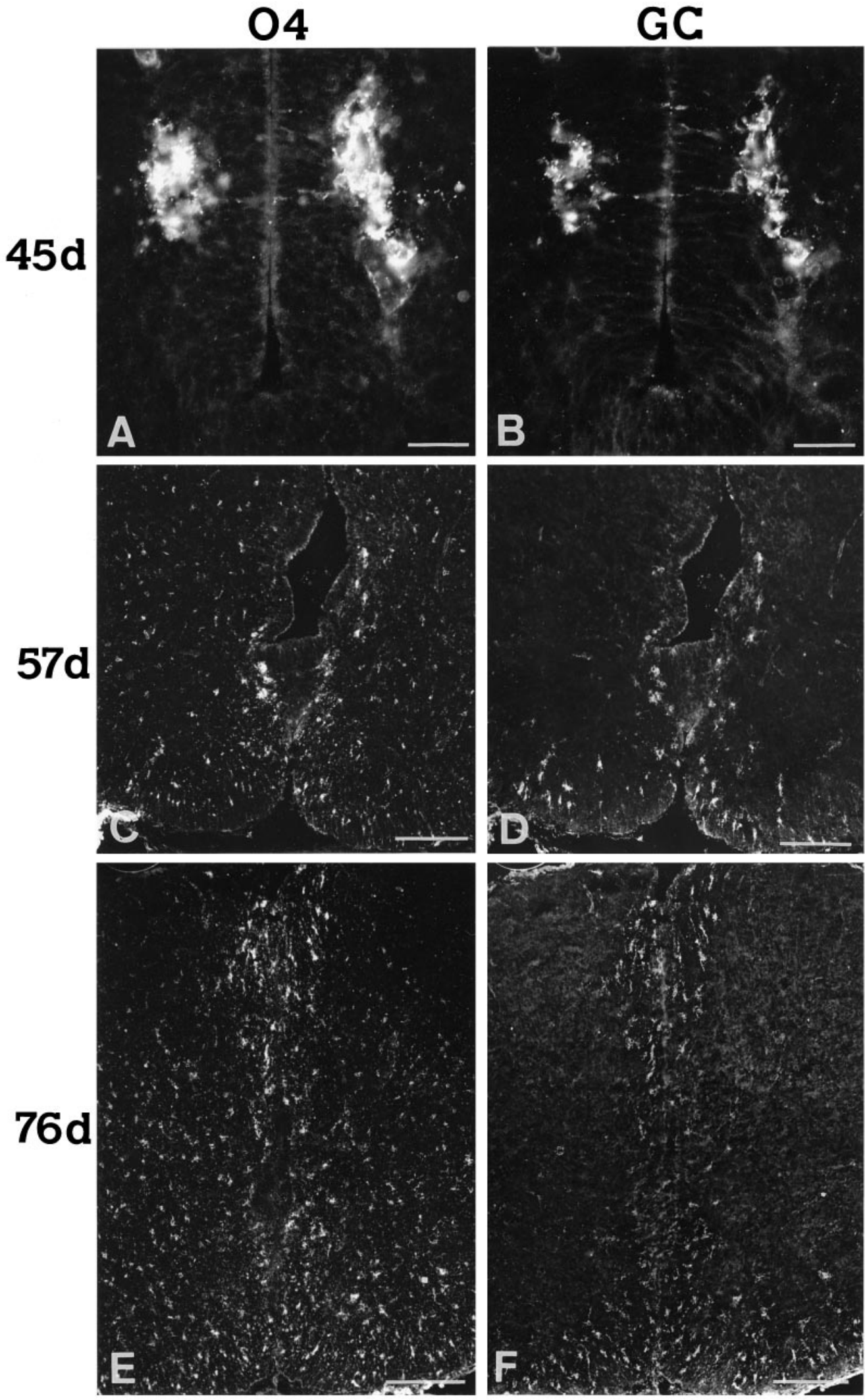

Figure 2. Emergence and dispersion of cells immunostained by $\mathrm{O} 4$ and Rmab antibodies in the human embryonic spinal cord. Cryostat sections of formaldehyde-fixed spinal cord of $45(A, B), 57(C, D)$, and $76(E, F)$ dpc were double-stained with $\mathrm{O} 4(A, C, E)$ and Rmab (called $G C ; B, D, F)$ antibodies. In $A$ and $B$, note the presence of two intensely stained $\mathrm{O}^{+}$clusters of cells just dorsal to floor plate with a more delicate co-label with Rmab and a few stained cell processes going into the VZ. In $C$ and $D$, the ventral two-thirds of the cord is shown. In $E$ and $F$, both the ventral and dorsal regions of the cord are shown with the midline at center and the ventral region at the bottom. At this stage, $\mathrm{O}^{+} / \mathrm{Rmab}^{+}$cells are also detected in the dorsal region. Note the presence of scattered $\mathrm{O}^{+}$cells not co-labeled by Rmab in the forming gray matter at both 57 and $76 \mathrm{dpc}$. Scale bars: $A, B, 50 \mu \mathrm{m} ; C-F, 200 \mu \mathrm{m}$. 


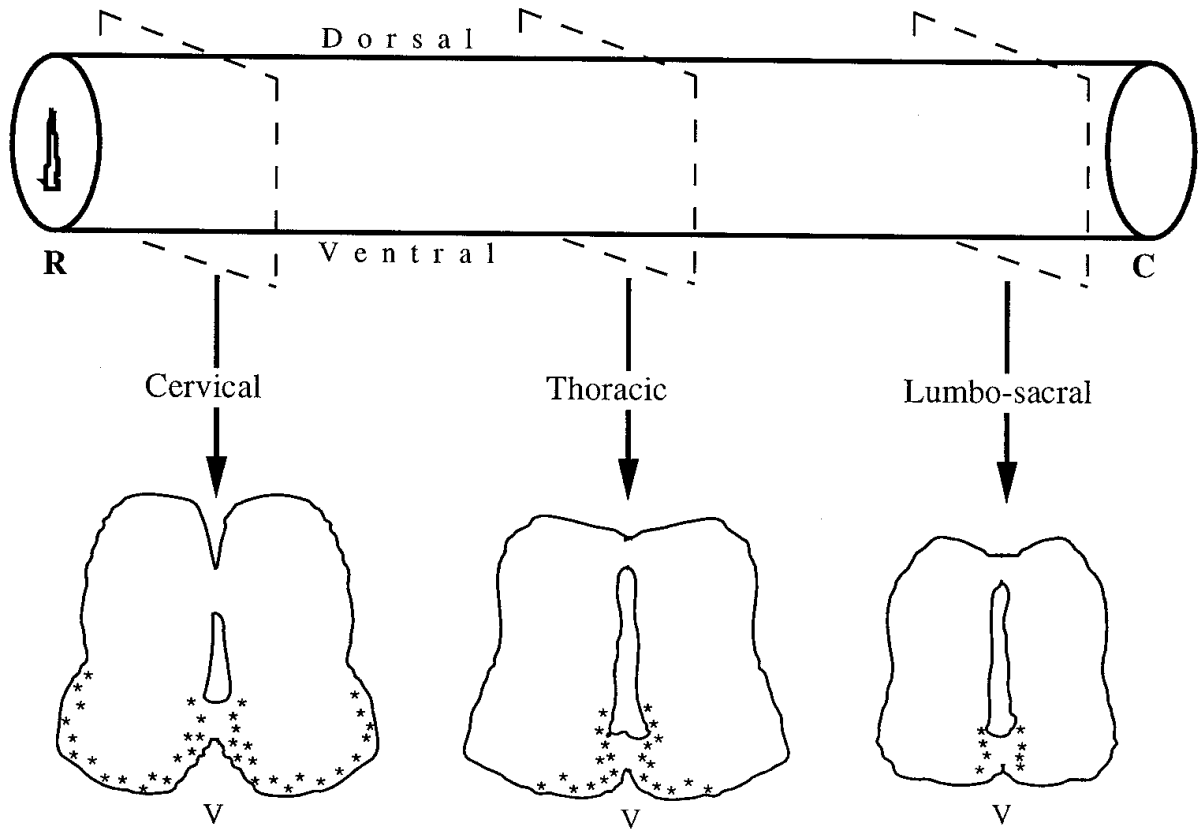

Figure 3. Rostrocaudal gradient of lateral dispersion of $\mathrm{MBP}^{+}$oligodendrocyte precursors in the spinal cord at $57 \mathrm{dpc}$. In vibratome cervical cord sections, $\mathrm{MBP}^{+}$cells occupy the entire ventral and lateral part of the forming white matter. At the thoracic level, $\mathrm{MBP}^{+}$cells are detected on each side of the floor plate spreading into the ventral region, whereas at the lumbar level these cells are restricted to each side of the ventral VZ and floor plate.
(IZ), which will become the gray matter, whereas oligodendrocytes appear later and myelinate axons within the MZ, which will become the white matter. For the sake of clarity, we will call the IZ the forming gray matter and the MZ the forming white matter. This entire study was performed on transversal vibratome or cryostat sections of 32 embryonic and fetal spinal cords, 29 of which are recorded in Table 1.

\section{Oligodendrocyte precursors first appear in the ventral region and later in the lateral regions of the spinal cord}

Vibratome sections were stained with antibodies against the myelin proteins $\mathrm{MBP}$ and $\mathrm{CNP}$, and cryostat sections were labeled with antibodies recognizing specific glycolipids expressed at various stages of oligodendrocyte development (Bansal et al., 1989). In sections of 45-52 dpc, two distinct clusters of cells expressing MBP and CNP or binding O4 and Rmab (but not O1) antibodies were found on each side of the ependymal canal, juxtaposed against the VZ cells of the ventral cord and situated just dorsal to the floor plate (Tables 1, 2; Figs. $1 A-C, 2 A, B$ ). At 45 dpc, these cell clusters were detected along the entire length of the developing cord, although clusters in the cervical cord contained more cells than those of the caudal. Each cluster was more strongly labeled with MBP than with CNP antibodies. Double-labeling of sections with $\mathrm{O} 4$ and $\mathrm{Rmab}$ antibodies showed that $\mathrm{O} 4$ labeling was more intense than Rmab staining on the same cell clusters (Fig. $2 A, B$ ) and that a few cell processes stained by $\mathrm{O} 4$ or Rmab antibodies extended into the $\mathrm{VZ}$ (see previously cited references). Although the tight clustering of $\mathrm{O}^{+}$cells did not allow precise definition of their contours, some of these cells already appeared to be multipolar. Cells expressing glycolipids and/or MBP and CNP will be referred to as oligodendrocyte precursors.

From $53 \mathrm{dpc}$ on, such oligodendrocyte precursors became more numerous, and $\mathrm{O} 1$ immunoreactivity recognizing $\mathrm{GC}$ was detected for the first time in a subpopulation of $\mathrm{O}^{+}$cells when alternate adjacent sections were stained with each antibody (Table 2). Oligodendrocyte precursors appeared to disperse away from the clusters described above: cells stained by MBP or Rmab were now detected in the ventral region of the cord on either side of the floor plate (Figs. $1 C, 2 D$ ). $\mathrm{O}^{+}$only cells (and to a lesser extent $\mathrm{Rmab}$ and $\mathrm{MBP}^{+}$cells) could also be seen dispersing laterally and even dorsally, parallel to the VZ, toward the forming gray matter (Figs. $1 C$, arrows, $2 C, E$ ). At $57 \mathrm{dpc}$, many oligodendrocyte precursors occupied the ventral region of the forming white matter of the cord (Figs. $1 G, 2 C$ ).

Examination of the pattern of emergence of $\mathrm{MBP}^{+}$cells at different axial levels of three cords at $57 \mathrm{dpc}$ revealed a rostrocaudal gradient (Fig. 3). In the cervical cord, $\mathrm{MBP}^{+}$cells were present in the entire ventral region of the forming white matter (Fig. $1 G$ ), whereas they were restricted to the ventral area close to the floor plate in the lumbar region, as observed $3 \mathrm{~d}$ previously in the cervical sections (Fig. 1C). Although $\mathrm{MBP}$ or $\mathrm{CNP}^{+}$cells close to the floor plate were multipolar, some of the ventrolateral cells showed processes oriented more radially (Fig. 2C,D), possibly along axons or radial glia (Choi, 1981).

To determine whether shh was present within the human embryonic spinal cord when oligodendrocyte lineage cells emerge, vibratome sections of spinal cord of various ages were immunolabeled with anti-sh antibody. Shh was expressed by floor plate cells at $45 \mathrm{dpc}$ (Fig. 1D) and remained restricted to this region with the staining becoming progressively weaker at later developmental stages (Fig. 1D-F).

\section{Emergence of oligodendrocyte precursors in the dorsal spinal cord}

Oligodendrocyte precursors were first detected in the dorsal half of embryonic spinal cord sections at $74 \mathrm{dpc}$ (Table 1). Most of these cells were located in the dorsal region of the forming white matter close to the midline, although some precursors also populated the dorsolateral rims of the cord. Thus, at $76 \mathrm{dpc}$, oligodendrocyte precursors labeled by the $\mathrm{O} 4$ and Rmab antibodies were present in both ventral and dorsal white matter regions (Fig. $2 E, F)$. In contrast, the majority of oligodendrocyte precursors found in the dorsal or ventral regions of the gray matter at this age were $\mathrm{O}^{+}{ }^{+}$, Rmab cells (Fig. $2 E, F$ ). $\mathrm{O}^{+}$cells were more numerous at $76 \mathrm{dpc}$ than at earlier ages and were found in ventral and dorsal presumptive white matter but were more frequent in the ventral region (Table 2). 


\section{MBP}
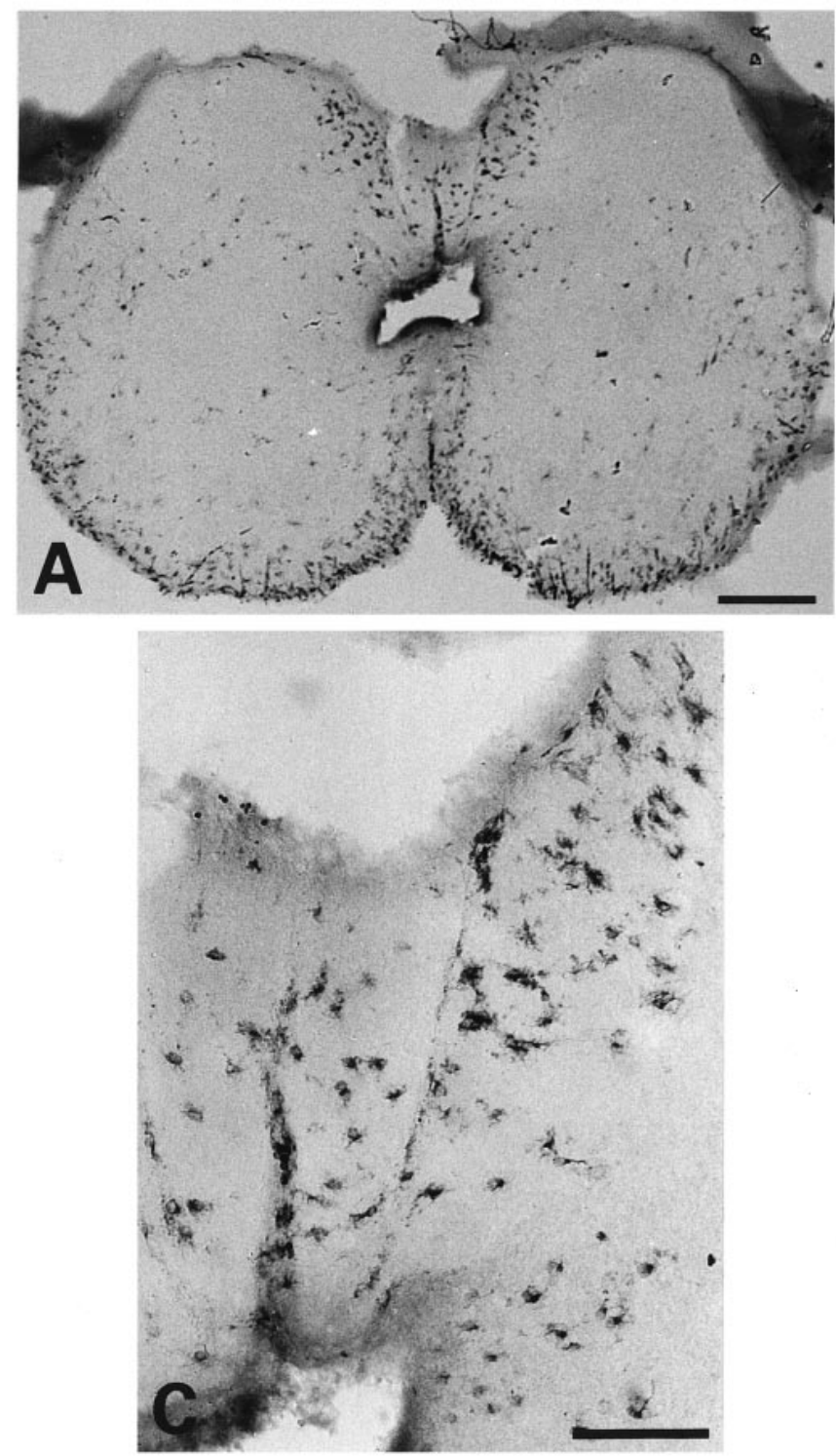

\section{CNP}
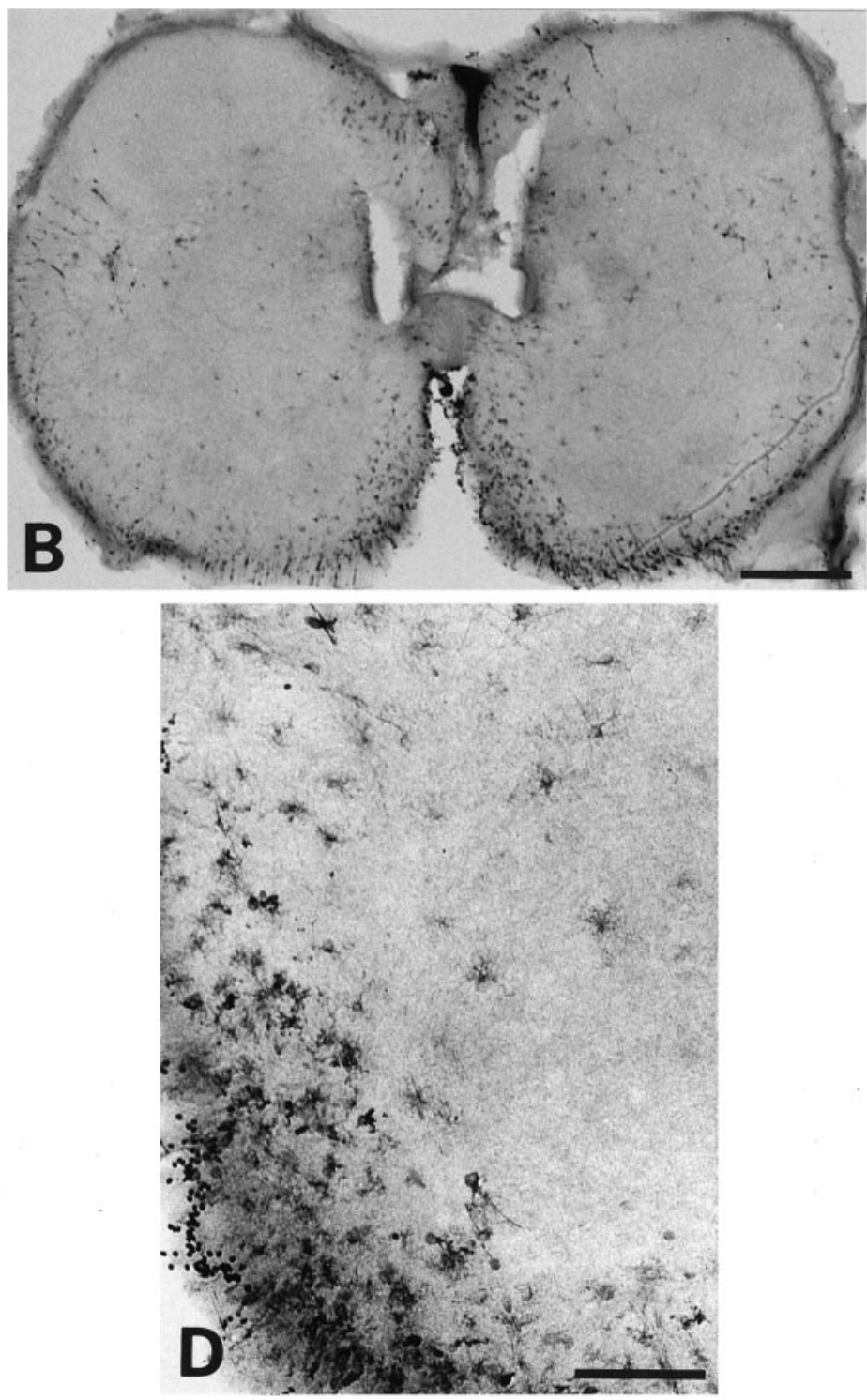

Figure 4. Location of cells expressing MBP or CNP in the dorsal and ventral spinal cord at $83 \mathrm{dpc}$. Immunoperoxidase labeling of Bouin's-fixed vibratome sections. The majority of $\mathrm{MBP}^{+}(A, C)$ or $\mathrm{CNP}^{+}(B, D)$ cells at this age is found in the ventral and dorsal forming white matter. Note the intense staining of ventral roots probably corresponding to the formation of thin myelin internodes. In $C$, the dorsal oligodendrocytes show a less complex network of processes than those of the ventral region shown in $D$. Scale bars: $A, B, 200 \mu \mathrm{m} ; C, D, 100 \mu \mathrm{m}$.

It has been shown previously that at $11 \mathrm{WG}$, short myelinated segments can be seen at the anterior roots at the cervical level (Weidenheim et al., 1993). Accordingly, in sections of 83 dpc cord, $\mathrm{MBP}^{+}$or $\mathrm{CNP}^{+}$cells were seen along discrete MBP-stained segments, which may correspond to thin myelin internodes in the ventral roots (Fig. 4A,B).

\section{Oligodendrocyte precursors express the PCNA and PDGF-R $\alpha$}

To determine whether oligodendrocyte precursor cells were dividing, sections were double-labeled with $\mathrm{O} 4$ or $\mathrm{O} 1$ antibodies and an antibody to PCNA. PCNA protein accumulates in the G1 phase, is most abundant during the $\mathrm{S}$ phase, and is therefore used as a marker for actively proliferating cells (Bravo et al., 1987). From 45 to $53 \mathrm{dpc}$, very few $\mathrm{PCNA}^{+}$cells were found within the forming ventral gray or white matter of the spinal cord. The appearance of $\mathrm{PCNA}^{+}$cells outside the $\mathrm{VZ}$ at these ages paralleled the emergence of oligodendrocyte precursors (Fig. 5A,B). In sections of $57 \mathrm{dpc}$ cord, the nuclei of $\sim 60 \%$ of $\mathrm{O}^{+}$cells were labeled with PCNA (Fig. 5C,E,F). PCNA antibody also stained the nuclei of radially aligned precursors in the most ventrolateral part of the presumptive white matter (Fig.

Figure 5. Expression of PCNA by dispersing $\mathrm{O}^{+}$oligodendrocyte precursors. At $45 \mathrm{dpc}$, the ventral forming white and gray matters are virtually free of PCNA (FITC green label)-expressing cells $(A)$, a stage at which two foci of $\mathrm{O}^{+}$cells (RITC red label) can be detected juxtaposed to the ventral VZ $(B)$. ( $B$ shows double label for PCNA/O4 on a section adjacent to that shown in $A$.) At $57 \mathrm{dpc}(E$, $F$; see the locations of these regions drawn in $C)$, the majority of $\mathrm{O}^{+}$cells (red) has nuclei stained with anti-PCNA antibody (green). Figure legend continues. 

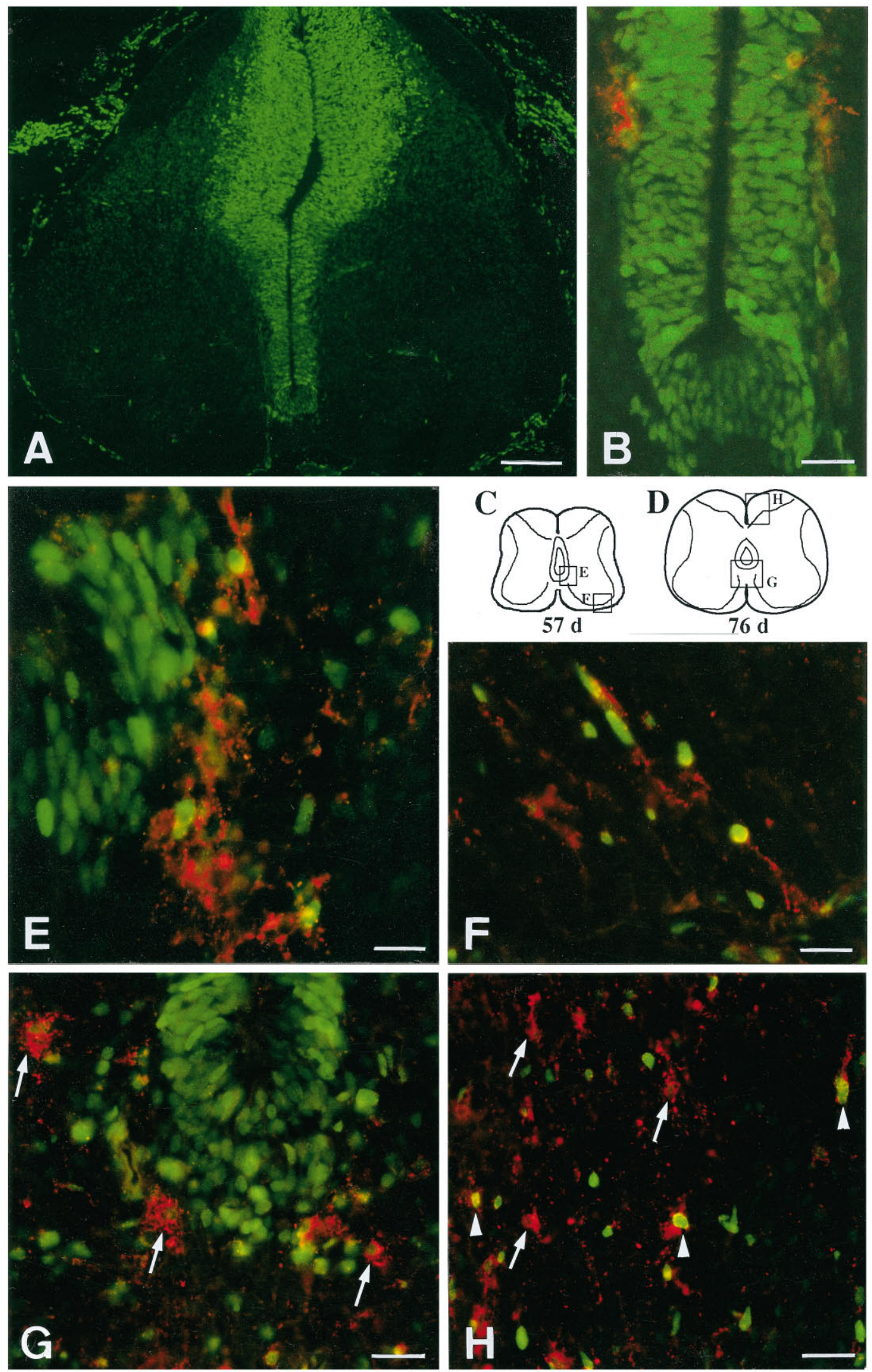

These double-labeled cells are either close to their site of origin on the side of the ventral VZ, which contains many PCNA ${ }^{+}$cells (on the left in $E$ ), or they are dispersed into the ventrolateral forming white matter $(F)$. At $76 \mathrm{dpc}(G, H$; see the locations of these regions drawn in $D)$, PCNA is absent from $\mathrm{O}^{+}$cells close to ventral VZ (arrows in $G$ ), but is present in some $4^{+}$cells in the dorsal cord region (arrowheads in $H$ ), whereas other O4 ${ }^{+}$cells are PCNA $^{-}$(arrows in $H$ ). Scale bars: $A, 200 \mu \mathrm{m} ; B, G, H, 30 \mu \mathrm{m} ; E, F, 15 \mu \mathrm{m}$. 
Table 1. Detection of MBP, CNP, and/or glycolipids expressing cells in the human fetal spinal cord at different postconceptional ages

\begin{tabular}{|c|c|c|c|c|c|}
\hline \multirow[b]{2}{*}{$\begin{array}{l}\text { Age } \\
(\mathrm{dpc})\end{array}$} & \multirow{2}{*}{$\begin{array}{l}\text { No. of } \\
\text { specimens } \\
\text { analyzed }\end{array}$} & \multicolumn{3}{|l|}{ Ventral half } & \multirow{2}{*}{$\begin{array}{l}\text { Dorsal half } \\
\text { Dorsal forming } \\
\text { white matter* }\end{array}$} \\
\hline & & $\begin{array}{l}\text { Adjacent to } \\
\text { VZ }\end{array}$ & $\begin{array}{l}\text { Either side of } \\
\text { the floor plate }\end{array}$ & $\begin{array}{l}\text { Lateral forming } \\
\text { white matter* }\end{array}$ & \\
\hline $45-52$ & 6 & + & - & - & - \\
\hline $53-54$ & 6 & + & + & - & - \\
\hline 57 & 8 & + & + & + & - \\
\hline $74-83$ & 9 & $+* *$ & + & + & + \\
\hline
\end{tabular}

Presence $(+)$ or absence $(-)$ of cells stained by MBP or CNP, O4, or Rmab antibodies in the spinal cord sections.

${ }^{*} \mathrm{O}^{+}$cells were also present in gray matter in this region, although in smaller numbers than in white matter.

**At these ages oligodendrocyte precursors were close to, but not juxtaposed to, the VZ.

Table 2. Appearance and distribution of $\mathrm{O1}^{+}$cells in the human fetal spinal cord at different postconceptional ages

\begin{tabular}{|c|c|c|c|c|c|}
\hline \multirow[b]{2}{*}{$\begin{array}{l}\text { Age } \\
(\mathrm{dpc})\end{array}$} & \multirow{2}{*}{$\begin{array}{l}\text { No. of } \\
\text { specimens } \\
\text { analyzed } \\
\end{array}$} & \multicolumn{3}{|l|}{ Ventral half } & \multirow{2}{*}{$\begin{array}{l}\text { Dorsal half } \\
\begin{array}{l}\text { Lateral forming } \\
\text { white matter* }\end{array}\end{array}$} \\
\hline & & $\begin{array}{l}\text { Adjacent to } \\
\text { VZ }\end{array}$ & $\begin{array}{l}\text { Either side of } \\
\text { the floor plate }\end{array}$ & $\begin{array}{l}\text { Lateral forming } \\
\text { white matter }\end{array}$ & \\
\hline $45-49$ & 4 & - & - & - & - \\
\hline $53-54$ & 3 & + & + & - & - \\
\hline $57-59$ & 5 & + & + & + & - \\
\hline $74-83$ & 5 & + & + & + & $+^{*}$ \\
\hline
\end{tabular}

Presence $(+)$ or absence $(-)$ of $\mathrm{O}^{+}$cells in the spinal cord sections.

*Fewer $\mathrm{O}^{+}$cells were found in the dorsal as compared with ventral parts of the cord at these ages.

$5 F)$. As expected, the nuclei of motor neurons of the ventral horn, which are postmitotic at this stage, were not labeled by PCNA antibodies (Fig. $5 A$ ). At $76 \mathrm{dpc}$, most ventrally located $\mathrm{O}^{+}$cells were $\mathrm{PCNA}^{-}$, whereas both $\mathrm{O}^{+} / \mathrm{PCNA}^{+}$and $\mathrm{O}^{+} / \mathrm{PCNA}^{-}$cells could be found in the dorsal forming white matter regions (Fig. $5 D, G, H)$. None of the $\mathrm{O}^{+}$cells showed PCNA label in their nuclei at this or an earlier age (data not shown).

We also examined the expression of the PDGF-R $\alpha$, because PDGF is a potent mitogen for oligodendrocyte progenitors and PDGF-R $\alpha$ expression is detected at E14 rat embryonic spinal cord (Pringle and Richardson, 1993; Yu et al., 1994). We stained sections of human spinal cord at 45, 49, 57, 76, and 83 dpc with PDGF-R $\alpha$ antibody and found that $\mathrm{O}^{+}$precursor cells expressed PDGF-R $\alpha$ at all of these ages (Fig. 6). The PDGF-R $\alpha$ dotted membrane label was detected on their cell body and on processes in the typical cell clusters located on each side of the ependymal canal (Fig. 6A-C). Other $\mathrm{O}^{+}$cells at later stages had dotted PDGF-R $\alpha$ label, mostly on the cell body or along the emergence of one process (Fig. $6 D-G$ ). Thus two antigens associated with proliferating cells in the oligodendrocyte lineage were found on $\mathrm{O}^{+}$precursor cells.

\section{Pattern of myelin gene expression by oligodendrocyte precursors also points to their origin in the ventral spinal cord}

To determine whether oligodendrocyte precursors also express the major myelin gene transcripts, we performed in situ hybridization with riboprobes specific for MBP and PLP. The pattern of expression of PLP and MBP transcripts was found to coincide broadly with the emergence of oligodendrocyte precursors described above (Fig. 7). At 45 dpc, MBP and PLP transcripts were detected in two symmetrical foci on either side of the ependymal canal in the ventral spinal cord only (Fig. 7A,B), yet the domain of PLP expression differed partially from that of MBP, because PLP transcripts extended into the VZ layer and more dorsally than MBP transcripts (Fig. 7A,B). At $57 \mathrm{dpc}$, both PLP and MBP transcripts were detected as clusters of grains probably associated with cells that had dispersed on either side of the floor plate and in ventrolateral regions of the forming white matter, just as was observed with $\mathrm{MBP}$ or $\mathrm{O}^{+}$cells at that stage. Unlike $\mathrm{O}^{+}$precursors, however, cells expressing PLP or MBP transcripts were rarely detected in the gray matter (Fig. $7 C, D$ ). At 76 dpc, PLP and MBP transcripts were found associated with cells not only in the ventral but also in the dorsal forming white matter of the cord (Fig. $7 E, F)$. At this stage, clusters of MBP or PLP transcripts were also present in the gray matter (Fig. $7 E, F$ ). Although we attempted repeatedly to detect PDGF-R $\alpha$ or CNP transcripts, no significant hybridization signal was observed at any age, possibly because RNA levels were too low or partially degraded in these human tissue samples.

We had the very rare opportunity to examine myelin gene transcripts in one $\sim 30 \mathrm{dpc}$ human embryo. Although no hybridization could be observed with MBP, a strong PLP/DM20 signal was detected in the ventral two-thirds of the neural tube (Fig. 8). Thus, the domain of expression of PLP/DM20 transcripts in the ependymal layer extended more dorsally at $30 \mathrm{dpc}$ than at $45 \mathrm{dpc}$, but was absent from the floor plate cells as well as from the newly formed IZ of the neural tube (Fig. 8). No staining with O4, O1, or Rmab antibodies was seen at this age. Thus in humans, PLP/DM20 transcripts are expressed very early in several CNS regions in which MBP transcripts are not detected.

\section{DISCUSSION}

In the present study, we describe the early emergence of oligodendrocyte precursors in the human embryonic spinal cord at 45 $\mathrm{dpc}$ in two discrete regions on each side of the ventral VZ. These cells first appear dorsal to the floor plate, emerge later in the ventral and lateral cord, and finally in dorsal regions of the presumptive white matter, a pattern of development similar to that observed in chick and rodents. The presence of $\mathrm{MBP}^{+}$cells has been observed before in the ventral human spinal cord at 9-10 


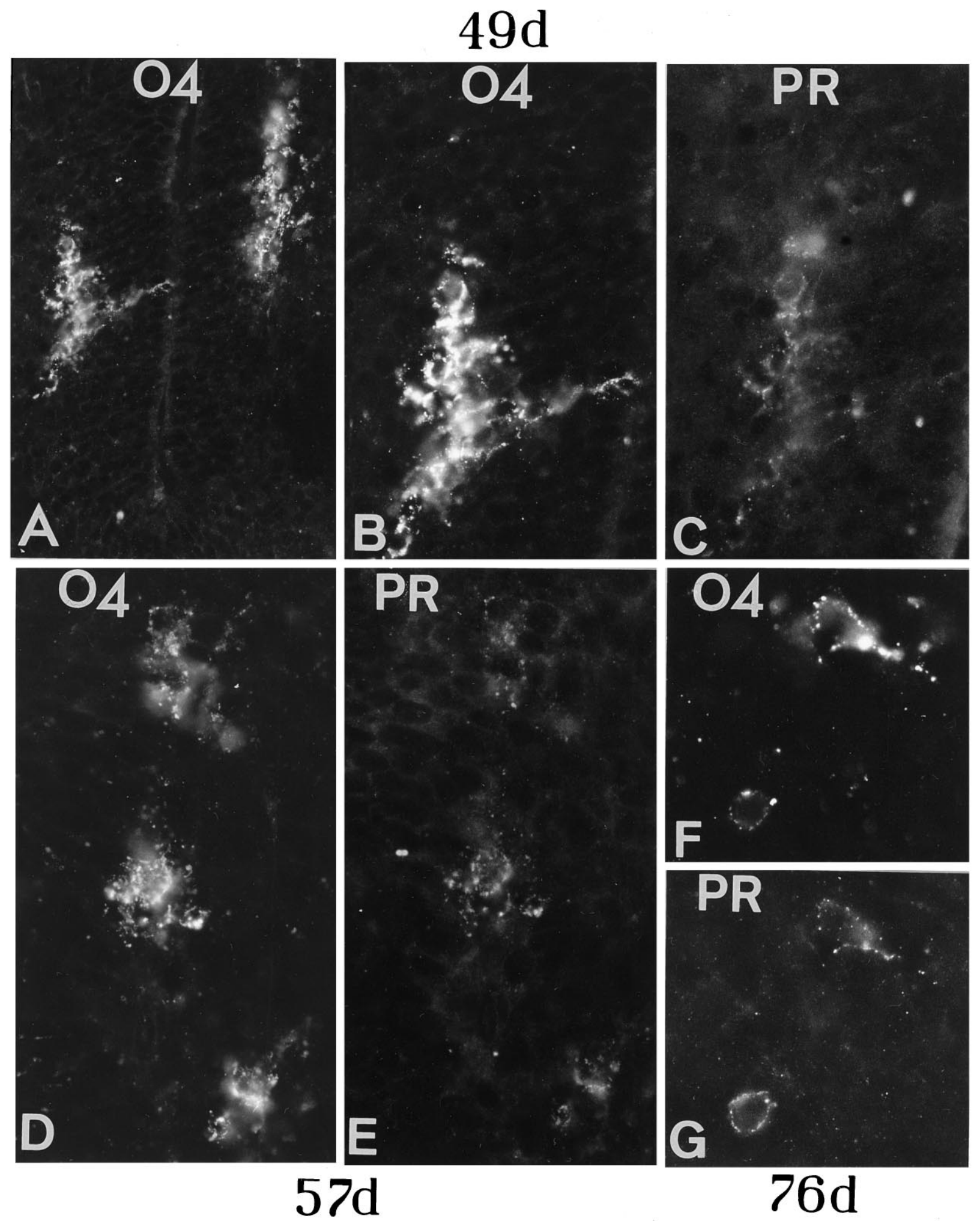

Figure 6. O4 precursors express PDGF-R $\alpha$. In these cryostat sections at $49 \mathrm{dpc}$, two clusters of $\mathrm{O}^{+}$cells on each side of the $\mathrm{VZ}$ in the ventral spinal cord ( $A, B$; compare with Fig. $2 A)$ express PDGF-R $\alpha$ (labeled PR), appearing as discrete dots on the cell body and processes $(B$ and $C$ show a closeup of the same cell, which is stained with $\mathrm{O} 4$ antibody on the left in $A)$. At $57(D, E)$ and $76 \mathrm{dpc}(F, G)$, cells located in the ventrolateral cord region on each side of the floor plate are double-labeled with O4 and PDGF-R $\alpha$ antibodies and show either several short processes or only one $(F, G)$. Magnification: $A, 322 \times ; B, C, 400 \times ; D, E, 500 \times ; F, G, 588 \times$. 

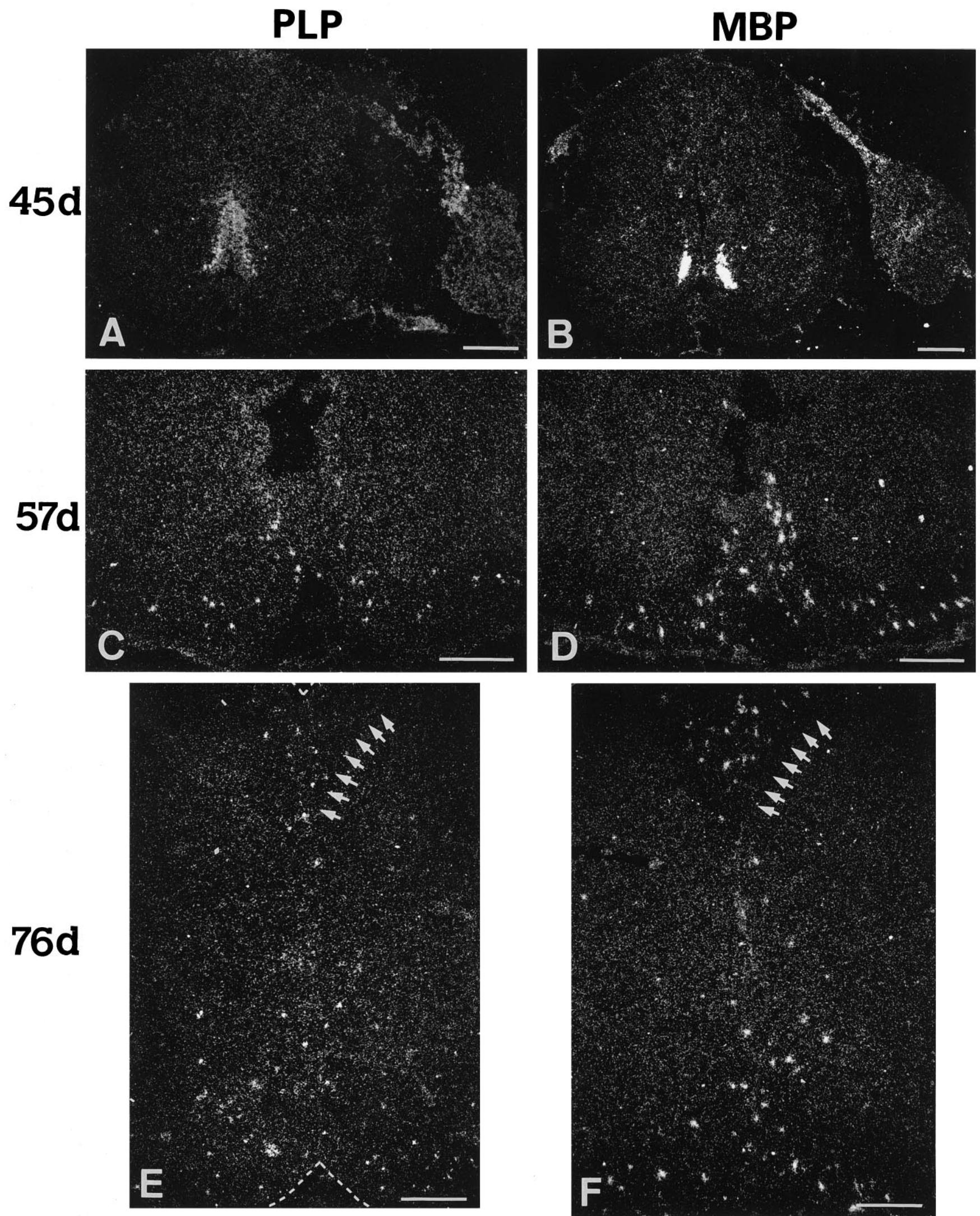

Figure 7. Origin and dispersion of cells expressing PLP/DM20 and MBP transcripts in the spinal cord. Expression pattern of PLP/DM20 (labeled PLP in $A, C, E)$ and $\mathrm{MBP}(B, D, F)$ transcripts at 45,57 , and $76 \mathrm{dpc}$ of human spinal cord development, as revealed by in situ hybridization using ${ }^{35} \mathrm{~S}$-labeled riboprobes on cryostat sections. Two foci of PLP/DM20 or MBP transcripts are detected in the ventral cord at $45 \mathrm{dpc}(A, B)$. Figure legend continues. 

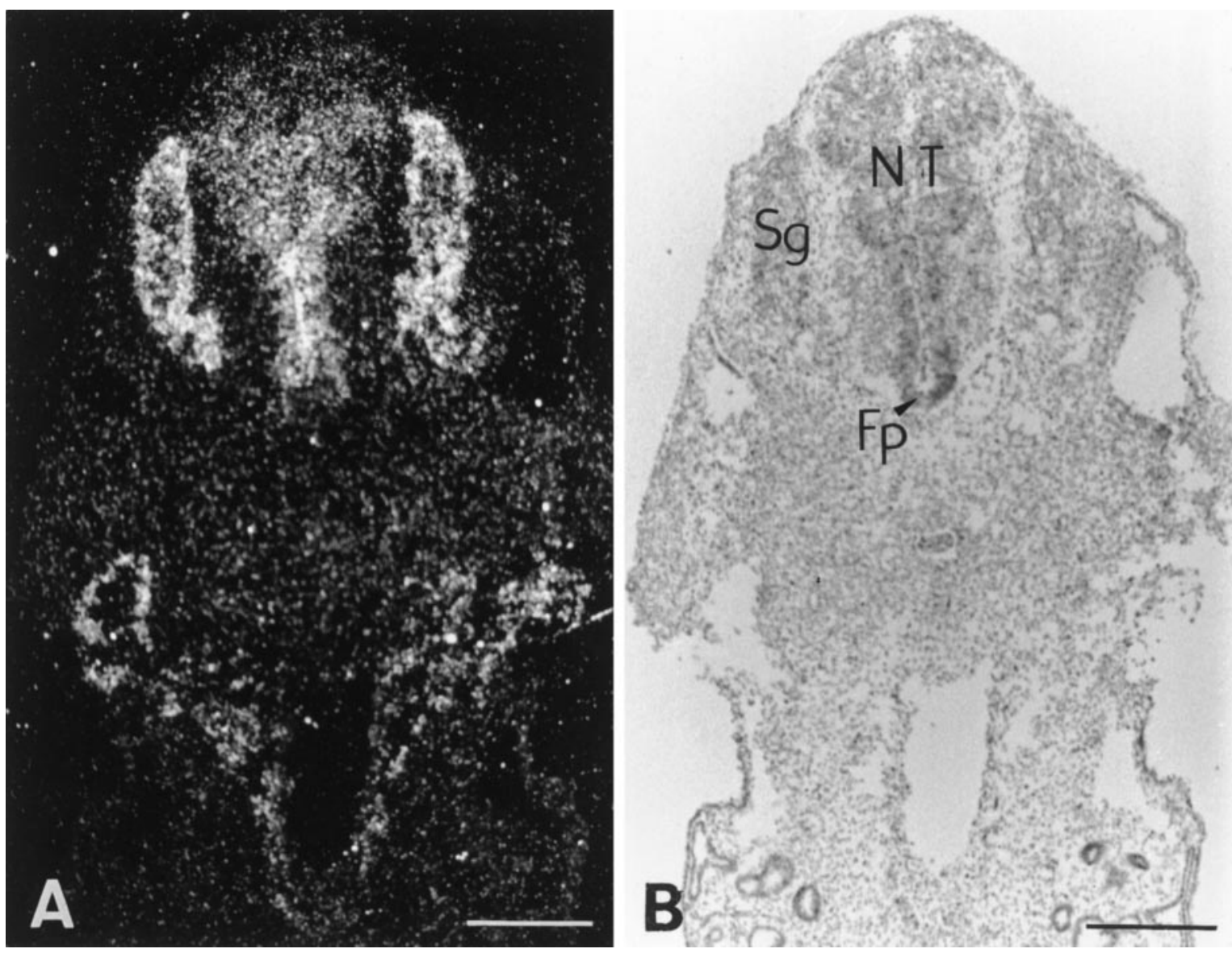

Figure 8. PLP/DM20 transcripts expression within human embryonic CNS at $30 \mathrm{dpc}$. PLP/DM20 transcripts are detected in the ventral two-thirds of the developing neural tube $(N T)$. Signal is absent from the floor plate $(F p)$ as well as from the forming IZ of the neural tube (identified on the hematoxylin-stained section viewed under bright field in $B$ ). There is also a strong bilateral signal for PLP/DM20 transcripts outside the CNS in what we identify as spinal ganglia $(\mathrm{Sg})$, as well as on a group of cells that appear to populate the gut. No signal for MBP transcripts was found at this age. Scale bars, $200 \mu \mathrm{m}$.

WG (Weidenheim at al., 1993). In our study, clusters of cells that stained with MBP and CNP antibodies could already be detected at $45 \mathrm{dpc}, \sim 30 \mathrm{~d}$ before the first myelin internodes appear in the ventral roots (see previously cited references). We also observed at similar times and locations oligodendrocyte precursors expressing MBP and PLP/DM20 transcripts as well as glycolipids that define specific stages of oligodendrocyte development in rat and man (Armstrong et al., 1992; Pfeiffer et al., 1993). Finally, we identify in these sites a population of $\mathrm{O}^{+}$cells with mitogenic potential and expressing the PDGF-R $\alpha$ protein, which suggests that PDGF may trigger these oligodendrocyte precursors to divide and migrate as it does in rat oligodendrocyte progenitors (Armstrong et al., 1990; Richardson et al., 1996). The presence of a rostrocaudal gradient of appearance of $\mathrm{MBP}^{+}$oligodendrocyte precursors within the ventral human spinal cord correlates well with the initial closure of the neural tube at the cervical level, the early generation of neurons in this region, and the development of the anterior limb (O'Rahilly and Müller, 1994).

The close overlap in timing of emergence and location of cells expressing sets of myelin gene transcripts or proteins and those expressing glycolipids and PDGF-R $\alpha$ suggests that some of these precursors may express myelin gene transcripts and proteins. At $45 \mathrm{dpc}, \mathrm{O}^{+} / \mathrm{PDGF}-\alpha / \mathrm{Rmab}^{+}$cell clusters indeed appear in the same regions where $\mathrm{CNP}$ or $\mathrm{MBP}^{+}$cells are detected or MBP or DM20/PLP transcripts emerge (with the exception of the DM20/PLP transcripts within the VZ). At 54 dpc, $\mathrm{PCNA}^{+}$stained with $\mathrm{O} 4$ antibody (probably detecting POA) or PDGF-R $\alpha$ cells appear to migrate radially toward the lateral gray and white matter and to disperse further laterally and dorsally. Another subset of $\mathrm{O}^{+}$cells located in the ventral, lateral, and dorsal forming white matter reacts with Rmab antibodies, may express myelin genes, and may evolve into

\section{$\leftarrow$}

Note that the domain of expression of PLP/DM20 transcripts at this age is wider and spreading more dorsally into the VZ, whereas the MBP transcripts seem to coincide mostly with the two clusters of oligodendrocyte precursors detected with MBP and O4 antibody staining (see Figs. $1 B, 2 A$ ). Note a discrete but definite signal for these transcripts in the dorsal $(B)$ and ventral roots $(A)$ on the right of the cord sections. At $57 \mathrm{dpc}$, clusters of PLP/DM20 and MBP transcripts, probably associated with cells, are now dispersed in the ventral forming white matter $(C, D)$, and at 76 dpc $(E, D)$ they become detectable in both the dorsal (on the left of the row of short arrows in $E$ and $D$ ) and ventral forming white matter. (Such transcript clusters could also be detected in the lateral spinal cord at this age; not illustrated here.) Scale bars, $200 \mu \mathrm{m}$. 
postmitotic $\mathrm{PCNA}^{-} / \mathrm{O}^{+}$cells. Similarly, human oligodendrocyte precursors express GC with time in culture (Aloisi et al., 1992). Thus, $30 \mathrm{~d}$ before the start of myelination, early precursor cells emerging ventrally in the spinal cord may express myelin gene transcripts, whereas cells located in the forming white matter will later progress to a postmitotic differentiated stage.

These observations on early human oligodendrocyte development are similar to those made in rodents, where embryonic expression of certain myelin genes occurs long before myelination. DM20 transcripts and protein were already detected in human spinal cord at 18 WG by Northern and Western analysis (Kronquist et al., 1987). Here we detected by in situ hybridization PLP/DM20 transcripts in the VZ region of the neural tube at $30 \mathrm{dpc}$ and in the ventral $\mathrm{VZ}$ of the spinal cord at $45 \mathrm{dpc}$. Such transcripts were identified at the ventricular germinal layer in the diencephalic basal plate at E9.5 in the mouse (Timsit et al., 1995). This pattern of expression of DM20/PLP transcripts suggests that it may play a role in neurogenesis or in dorsoventral patterning of the neural tube. Cells expressing DM20/PLP transcripts were already found in the rat cord at E12 in a restricted region of the VZ just above the floor plate (Yu et al., 1994); these transcripts became undetectable until E16-18, when they reappeared in differentiating oligodendrocytes. Whether the early cells expressing PLP/DM20 transcripts in the VZ will have an oligodendrocyte fate is presently unclear.

E12-16 mouse brains also express some MBP transcripts, which may correspond to alternative spliced forms of Golli/MBP transcripts (Nakajima et al., 1993; Pribyl et al., 1996). The Golli/MBP is a transcriptional unit upstream of the MBP gene whose transcripts are detected in the 18-20 WG human fetal spinal cord, whereas the Golli protein is observed in developing oligodendrocytes and their processes (Pribyl et al., 1993, 1996). The human MBP riboprobe and monoclonal antibodies we used here may recognize either the HOG 7 Golli-encoded protein, which contains MBP exon 6, or any of the four known MBP isoforms that are already detected by immunoblotting in the 11 WG human spinal cord (Kamholz et al., 1986; Roth et al., 1987). The two isoforms of CNP (46 and $48 \mathrm{kDa}$ ) are recognized by the CNP polyclonal antibody we used, but the largest isoform is encoded by a transcript uniquely expressed in rat oligodendrocyte precursors (Scherer et al., 1994). In view of these observations, our finding of MBP and CNP staining as well as MBP transcripts at an early stage of oligodendrocyte development is not so surprising.

The location of oligodendrocyte precursors expressing myelin genes as well as PDGF-R $\alpha$ in the ventral spinal cord is consistent with in vitro observations in chick and rodent showing that oligodendrocytes of dorsal spinal cord are derived from precursors that migrate from the ventral cord (Miller, 1996). Proliferating oligodendrocyte precursors located dorsal to the floor plate developed into oligodendrocytes only in cultures derived from the ventral half of the cord in $\sim$ E13 mouse and E14 rat spinal cord (Warf et al., 1991; Noll and Miller, 1993; Timsit et al., 1995), yet dorsal parts of the spinal cord may have an independent potential to generate oligodendrocyte precursors, as suggested by isotopic and isochronic exchange of segments of cord between chick and quail embryos (Cameron-Curry and Le Douarin, 1995). Another transplantation study in the rat shows that CNS fragments of all levels of the mouse neural tube at E12.5, including cervical and lumbar spinal cords, have the potential to generate oligodendrocytes, suggesting that neural precursors throughout the neural tube can generate oligodendrocytes (Hardy and Friedrich, 1996). These observations in rodent are compatible with a local influence of a morphogen inducing a lineage commitment and/or differentiation only in restricted regions of the CNS. In our study, the data clearly suggest that oligodendrocyte precursors initially form in the ventral region of the human spinal cord.

Most recent studies have unraveled the inductive effects of the floor plate and shh on the oligodendrocyte lineage. When E4 dorsal explants in chick were cocultured with notochord or floor plate, numerous oligodendrocytes were found in dorsal explants, which would otherwise yield very few oligodendrocytes (Trousse et al., 1995). In stage 10-12 dorsal chick spinal cord, $\mathrm{O}^{+}$precursors could be induced by isochronic transplantation of a notochord in vivo and in vitro (Orentas and Miller, 1996). Multipotential neural precursors are likely to be scattered throughout the entire cord, which would explain that a notochord can induce oligodendrocyte dorsally in the chick (see previously cited reference). In the quail, grafting of a second notochord in an ectopic dorsolateral position induces a floor plate at that location and an ectopic cluster of oligodendrocyte precursors at the ventricularlevel in vivo and in vitro (Pringle et al., 1996). In addition, quail neural tube explants respond in a dose-dependent manner to treatment with the amino-terminal portion of shh by induction of oligodendrocytes. This process takes place several days after induction of motor neurons, as predicted from their timing of emergence in vivo, which precedes that of oligodendrocytes. Such inductive power of the floor plate and the presence of shh in the human floor plate suggest that this morphogen may also induce the local emergence of the two clusters of oligodendrocyte precursors in the ventral region of the human cord.

It has been proposed that signals emanating from differentiating motor neurons may trigger the appearance of $\mathrm{O}_{4}^{+}$precursors in the chick (Orentas and Miller, 1996). In addition, neuronal signals (such as PDGF) could stimulate oligodendrocytes precursors, once induced, to propagate in the cord (Armstrong et al., 1990; Richardson, 1996). Oligodendrocyte precursors migrating out of their site of origin may follow motor fibers exiting the cord to reach the ventrolateral regions or the commissural axons to reach the ventrodorsal regions (Miller, 1996). The presence of dividing dorsal precursors at $76 \mathrm{dpc}$ may represent continuous migration of ventrally derived precursors to this dorsal region. Oligodendrocyte precursors are able to migrate into different spinal cord regions when grafted in newborn rats (Tontsch et al., 1994). Therefore, although the induction of the oligodendrocyte lineage may occur locally in the ventral region, migration of oligodendrocyte precursors is likely to account for the dispersion pattern of these cells from the ventral to the lateral and dorsal regions of the cord.

In conclusion, our data provide evidence that within the developing human spinal cord oligodendrocytes emerge in a ventral location, and they show that such an origin is conserved from birds to humans. They also highlight that PLP/DM20 transcripts are expressed much earlier than other myelin genes in the developing human CNS. We describe here a precise succession of stages in the development of spinal cord human oligodendrocytes that express myelin proteins several weeks before myelination. Because CNS development in humans is much more prolonged than in rodents, it makes possible a clear dissection of these different stages of oligodendrocyte development.

\section{REFERENCES}

Aloisi F, Giampaolo A, Russo G, Peschle C, Levi G (1992) Developmental appearance, antigenic profile and proliferation of glial cells of the human embryonic spinal cord: an immunocytochemical study using dissociated cultured cells. Glia 5:171-181. 
Armstrong RC, Harvath L, Dubois-Dalcq M (1990) Astrocytes and O-2A glial progenitors migrate toward distinct molecules. J Neurosci Res 27:400-407.

Armstrong RC, Dorn HH, Hkufta CV, Friedman E, Dubois-Dalcq M (1992) Preoligodendrocytes from adult human CNS. J Neurosci 12:1538-1547.

Bansal R, Warrington AE, Gard AL, Rantscht B, Pfeiffer SE (1989) Multiple and novel specificities of monoclonal antibodies 01, 04, and $\mathrm{R}-\mathrm{mAb}$ used in the analysis of oligodendrocyte development. J Neurosci Res 24:548-557.

Bansal R, Stefansson K, Pfeiffer SE (1992) Prooligodendroblast antigen, a developmental antigen expressed by A007/O4-positive oligodendrocyte progenitors prior to the appearance of sulfatide and galactocerebroside. J Neurochem 58:2221-2229.

Barres BA, Raff MC (1996) Axonal control of oligodendrocyte development. In: Glial cell development: basic principles and clinical relevance (Jessen KR, Richardson WD, eds), pp 71-83. Oxford: Bios Scientific.

Bernier L, Alvarez F, Norgard EM, Raible DW, Mentaberry A, Schembri JG, Sabatini DD, Colman DR (1987) Molecular cloning of 2', 3'-cyclic nucleotide $3^{\prime}$-phosphodiesterase mRNAs with different $5^{\prime}$ ends encode the same set of proteins in nervous and lymphoid tissues. J Neurosci 7:2703-2710.

Braun PE, Sandillon F, Edwards A, Matthieu J-M, Privat A (1988) Immunocytochemical localization by electron microscopy of $2^{\prime}, 3^{\prime}$-cyclic nucleotide $3^{\prime}$-phosphodiesterase in developing oligodendrocytes of normal and mutant brain. J Neurosci 8:3057-3066.

Bravo R, Frank R, Blundell PA, MacDonald-Bravo H (1987) Cyclin/ PCNA is the auxiliary protein of DNA polymerase-delta. Nature 326:515-517.

Bumcrot DA, Takada R, McMahon AP (1995) Proteolytic processing yields two secreted forms of sonic hedgehog. Mol Cell Biol 75:2294-2303.

Cameron-Curry P, Le Douarin NM (1995) Oligodendrocyte precursors originate from both the dorsal and the ventral parts of the spinal cord. Neuron 15:1299-1310.

Choi BH (1981) Radial glia of the developing human foetal spinal cord: Golgi, immunohistochemical and electron microscopic study. Dev Brain Res 1:249-267.

Davis AA, Temple S (1994) A self-renewing multipotential stem cell in embryonic rat cerebral cortex. Nature 372:263-266.

Dickson JG, Kesselring L, Walsh FS, Davison AN (1985) Cellular distribution of $\mathrm{O} 4$ antigen and galactocerebroside in primary cultures of human foetal spinal cord. Acta Neuropathol 68:340-344.

Dubois-Dalcq M, Armstrong R (1992) The oligodendrocyte lineage during myelination and remyelination. In: Biology and chemistry (Martenson RE, ed), pp 81-122. Caldwell, NJ: Telford.

Dubois-Dalcq M, Behar T, Hudson LD, Lazzarini RA (1985) Emergence of three myelin proteins in oligodendrocytes cultured without neurons. J Cell Biol 102:384-392.

Ellison J, de Vellis J (1994) Platelet derived growth factor receptor is expressed by cells in the early oligodendrocyte lineage. J Neurosci Res $37: 116-128$.

Gamble HJ (1969) Electron microscope observations on the human foetal and embryonic spinal cord. J Anat 104:435-453.

Grove EA, Williams BP, Li D-Q, Hajihosseini M, Friedrich A, Price J (1993) Multiple restricted lineages in the embryonic rat cerebral cortex. Development 117:553-561.

Hardy RJ, Friedrich Jr VL (1996) Oligodendrocyte progenitors are generated throughout the embryonic mouse brain, but differentiate in restricted foci. Development 122:2059-2069.

Hudson LD (1990) The molecular biology of myelin proteins in the central and peripheral nervous systems. Semin Neurosci 2:483-496.

Ikenaka K, Kagawa T, Mikoshiba K (1992) Selective expression of DM20 , an alternatively spliced myelin proteolipid gene product, in the developing nervous system of the mouse. J Neurochem 58:2248-2253.

Jacobson M (1991) Neuroglial ontogeny. In: Developmental neurobiology, pp 95-117. New York: Plenum.

Jordan C, Friedrich Jr V, Dubois-Dalcq M (1989) In situ hybridization analysis of myelin gene transcripts in developing mouse spinal cord. J Neurosci 9:248-257.

Kamholz J, deFerra F, Puckett C, Lazzarini R (1986) Identification of three forms of human myelin basic protein by cDNA cloning. Proc Natl Acad Sci USA 83:4926-4966.
Kristensson K, Zeller NK, Dubois-Dalcq M, Lazzarini RA (1986) Expression of myelin basic protein gene in the developing rat brain as revealed by in situ hybridization. J Histochem Cytochem 34:467-473.

Kronquist KE, Crandall BF, Macklin WB, Campagnoni AT (1987) Expression of myelin proteins in the developing human spinal cord: cloning and sequencing of human proteolipid protein cDNA. J Neurosci Res 18:395-401.

Leber SM, Sanes JR (1995) Migratory paths of neurons and glia in the embryonic chick spinal cord. J Neurosci 15:1236-1248.

Lee K-H, Bowen-Pope DF, Reed RR (1990) Isolation and characterization of the platelet derived growth factor receptor from rat olfactory epithelium. Mol Cell Biol 10:2237-2246.

Levison SW, Goldman JE (1993) Both oligodendrocytes and astrocytes develop from progenitors in the subventricular zone of postnatal rat forebrain. Neuron 2:201-212.

Luskin MB, Parnavelas JG, Barfield A (1993) Neurons, astrocytes and oligodendrocytes of the rat cerebral cortex originate from separate progenitor cells: an ultrastructural analysis of clonally related cells. J Neurosci 13:1730-1750.

Marti E, Bumcrot DA, Takada R, McMahon AP (1995) Requirement of $19 \mathrm{~K}$ form of sonic hedgehog for induction of distinct ventral cell types in CNS explants. Nature 375:322-325.

McKinnon R, Matsui T, Dubois-Dalcq M, Aaronson S (1990) FGF modulates the PDGF-driven pathway of oligodendrocyte development in vitro. Neuron 5:603-614.

Miller RH (1996) Oligodendrocyte origins. Trends Neurosci 19:92-96.

Monge M, Kadiisky D, Jacque C, Zalc B (1986) Oligodendroglial expression and deposition of four major myelin constituents in the myelin sheath during development. Dev Neurosci 8:222-235.

Nakajima K, Ikenaka K, Kagawa T, Aruga J, Nakao J, Nakahira K, Shiota C, Kim SU, Mikoshiba K (1993) Novel isoforms of mouse myelin basic protein predominantly expressed in embryonic stage. J Neurochem $1554-1563$

Nishiyama A, Lin HH, Giese N, Heldin CH, Stallcup WB (1996) Colocalization of NG2 proteoglycan and PDGF a-receptor on O2A Progenitor Cells in the developing rat brain. J Neurosci Res 43:299-314.

Noll E, Miller RH (1993) Oligodendrocyte precursors originate at the ventral ventricular zone dorsal to the ventral midline in the embryonic rat spinal cord. Development 118:563-573.

Ono K, Bansal R, Payne J, Rutishauser U, Miller RH (1995) Early development and dispersal of oligodendrocyte precursors in the embryonic chick spinal cord. Development 121:1743-1754.

O'Rahilly R, Müller F (1994) The embryonic human brain, an atlas of developmental stages. New York: Wiley.

Orentas DM, Miller RH (1996) The origin of spinal cord oligodendrocytes is dependent on local influences from the notochord. Dev Biol 177:43-53.

Pfeiffer SE, Warrington AE, Bansal R (1993) The oligodendrocyte and its many cellular processes. Trends Cell Biol 3:191-197.

Pribyl TM, Campagnoni CW, Kampf K, Kashima T, Handley VW, McMahon J, Campagnoni AT (1993) The human myelin basic protein gene is included within a 179-kilobase transcription unit: expression in the immune and central nervous systems. Proc Natl Acad Sci USA 90:10695-10699.

Pribyl TM, Campagnoni CW, Kampf K, Ellison JA, Landry CF, Kashima T, Mac Mahon J, Campagnoni AT (1996) Expression of the myelin basic protein gene locus in neurons and oligodendrocytes in the human fetal central nervous system. J Comp Neurol, in press.

Pringle NP, Richardson WD (1993) A singularity of PDGF-receptor alpha expression in the dorsoventral axis of the neural tube may define the origin of the oligodendrocyte lineage. Development 115:535-551.

Pringle NP, Collarini EJ, Mosley MJ, Heldin C-H, Westermark B, Richardson WD (1989) PDGF A chain homodimers drive proliferation of bipotential (O-2A) glial progenitor cells in the developing rat optic nerve. EMBO J 8:1049-1056.

Pringle NP, Mudhar HS, Collarini EJ, Richardson WD (1992) PDGF receptors in the rat CNS: during late neurogenesis, PDGF alphareceptor expression appears to be restricted to the glial cells of the oligodendrocyte lineage. Development 115:535-551.

Pringle NP, Yu W-P, Guthrie S, Peterson AC, Richardson WD (1996) Determination of neuroepithelial cell fate: induction of the oligodendrocyte lineage by ventral midline cells and sonic hedgehog. Dev Biol 177:30-42.

Raff MC (1989) Glial cell diversification in the rat optic nerve. Science 243:1450-1455. 
Richardson WD, Pringle NP, Yu W-P, Collarini EJ, Hall A (1996) Origins and early development of oligodendrocytes. In: Glial cell development: basic principles and clinical relevance (Jessen KR, Richardson WD, eds), pp 53-70. Oxford: Bios Scientific.

Roelink H, Porter J, Chiang C, Tanabe Y, Chang DT, Beachy PA, Jessell TM (1995) Floor plate and motor neuron induction by different concentrations of the amino-terminal cleavage product of sonic hedgehog autoproteolysis. Cell 81:445-455.

Roth HJ, Kronquist KE, Kerlero E, de Rosbo N, Crandall BF, Campagnoni AT (1987) Expression of myelin proteins in the developing human spinal cord: cloning and sequencing of human proteolipid cDNA. J Neurosci Res 17:321-328.

Sato J, Kim SU (1994) Proliferation and differentiation of fetal human oligodendrocytes in culture. J Neurosci Res 39:260-272.

Scherer SS, Braun PE, Grinspan J, Collarini E, Wang D-Y, Kamholz J (1994) Differential regulation of the $2^{\prime}, 3^{\prime}$-cyclic nucleotide $3^{\prime}$ phosphodiesterase gene during oligodendrocyte development. Neuron 12:1363-1375.

Sommer I, Schachner M (1981) Monoclonal antibodies (O1 and O4) to oligodendrocyte cell surfaces: an immunocytological study in the central nervous system. Dev Biol 83:311-327.

Sprinkle TJ, McMorris AF, Yoshino J, De Vries G (1985) Differential expression of $2^{\prime}: 3^{\prime}$ cyclic nucleotides $3^{\prime}$ phosphodiesterase in cultured central, peripheral, and extraneural cells. Neurochem Res 10:919-931.

Timsit SG, Bally-Cuif L, Colman DR, Zalc B (1992) DM-20 mRNA is expressed during the embryonic development of the nervous system of the mouse. J Neurochem 58:1172-1175.

Timsit S, Martinez S, Allinquant B, Peyron F, Zalc B (1995) Oligo- dendrocytes originate in a restricted zone of the embryonic ventral neural tube defined by DM-20 mRNA expression. J Neurosci 15:1012-1024.

Tontsch U, Archer DR, Dubois-Dalcq M, Duncan ID (1994) Transplantation of an oligodendrocyte cell line leading to extensive myelination. Proc Natl Acad Sci USA 91:11616-11620.

Trousse F, Giess MC, Soula C, Ghandour S, Duprat A-M, Cochard P (1995) Notocord and floor plate stimulate oligodendrocyte differentiation in cultures of the chick dorsal neural tube. J Neurosci Res 41:552-560.

Warf BC, Fok-Seang J, Miller RH (1991) Evidence for the ventral origin of oligodendrocytes in the rat spinal cord. $\mathrm{J}$ Neurosci 11:2477-2488

Weidenheim KM, Kress Y, Epshteyn I, Rashbaum WK, Lyman WD (1992) Early myelination in the human foetal lumbosacral spinal cord: characterization by light and electron microscopy. J Neuropathol Exp Neurol 51:142-149.

Weidenheim KM, Epshteyn I, Rashbaum WK, Lyman WD (1993) Neuroanatomical localisation of myelin basic protein in the late first and early second trimester human foetal spinal cord and brainstem. J Neurocytol 22:507-516.

Williams BP, Price J (1995) Evidence for multiple precursor cell types in the embryonic rat cerebral cortex. Neuron 14:1181-1188.

Yu WP, Collarini EJ, Pringle NP, Richardson WD (1994) Embryonic expression of myelin genes: evidence for a focal source of oligodendrocyte precursors in the ventricular zone of the neural tube. Neuron 12:1353-1362. 